$\sqrt{B}$

J. bio-sci. 17: 135-138, 2009

ISSN 1023-8654

http://www.banglajol.info/index.php/JBS/index

\title{
ISOLATION AND IDENTIFICATION OF BACTERIA FROM THE WORKERS OF LIVE BIRD MARKETS AT MYMENSINGH, BANGLADESH
}

\author{
S Sarker", S Talukder ${ }^{1}$, E H Chowdhury, P M Das \\ Department of Pathology, Bangladesh Agricultural University, Mymensingh-2202, Bangladesh \\ ${ }^{1}$ Department of Animal Science \& Nutrition, Chittagong Veterinary \& Animal Sciences University, \\ Chittagong-4202, Bangladesh
}

\begin{abstract}
Context: Identification of bacteria from the workers of live bird markets is important factor for zoonotic aspects and for implementing appropriate control strategies.

Objectives: To determine the occurrence of bacteria especially Salmonella $\mathrm{sp}$. and Escherichia coli from the workers of live bird markets.

Materials and Methods: A total of 40 samples were collected from hand washes $(n=20)$ and nasal swabs $(n=20)$ of the associated workers in urban and suburban live bird markets. Bacteria were isolated in different media, and identification was performed based on the staining, cultural and some biochemical tests. For Salmonella sp., DNA was extracted using a DNA isolation kit and rfbs gene was amplified by using commercial PCR kit.

Results: The bacteria such as Salmonella sp. and E. coli were detected in the samples by several microbial tests. The prevalence of Salmonella sp. was $40 \%$ and $30 \%$, and E. coli was $70 \%$ and $40 \%$ in the hand washes and nasal swabs respectively of the workers of urban and periurban live bird markets.

Conclusion: The results obtained in this study suggest that the appropriate precautions should be taken during and subsequent to the handling of live birds to minimize the risk of zoonotic diseases.
\end{abstract}

Key words: Salmonella, Escherichia coli, live bird markets, isolation and identification

\section{Introduction}

In Bangladesh, large number of people in both urban and suburban locations are entirely dependent on live bird marketing. Transmission of bacteria from live bird markets to workers also occurred most probably due to low level of biosecurity practices. Common pathogenic bacteria that may be the cause of food borne diseases in human including strains of Salmonella sp. and Escherichia coli (Sockett 1991). In many developing countries, lack of appropriate slaughtering facilities and unsatisfactory slaughtering techniques were responsible for bacterial infection or contamination in human (Joshi et al. 2003). But literature is not available on the transmission of bacteria from the live bird markets to workers. Few reports are available for enteric pathogenic bacteria especially Salmonella sp. and E. coli of human that can also be isolated from migrating birds. These organisms are important in the context of transmission of potential human pathogens by migrating birds and the handling of birds by workers (Murray 2000, Tizard 2004). Therefore, the present study was undertaken to determine the prevalence of bacteria especially Salmonella sp. and $E$. coli in the hand washes and nasal swabs of the workers of live bird markets.

•Present address: Department of Animal Husbandry \& Veterinary Science, University of Rajshahi, Rajshahi-6205, subir_ahvs@ru.ac.bd 


\section{Materials and Methods}

Collection and culture of samples: The total of 40 samples of which twenty (20) hand wash (10 from urban and 10 from suburban) and 20 nasal swabs (10 from urban and 10 from suburban) were collected from the people working in live bird markets.

Test tubes containing samples were incubated for $24 \mathrm{~h}$ at $37^{\circ} \mathrm{C}$. From the cultured samples, subcultures were also made on nutrient agar, BGA agar, EMB agar and blood agar and incubated at $37^{\circ} \mathrm{C}$ for overnight. The identification of the organisms was performed by following the tests of Merchant and Packer (1967), Carter (1979), Freeman (1985) and Cheesbrough (2000). On the basis of colony, and staining characters and biochemical tests, the organisms were isolated and identified. The representative bacteria were stained using modified Gram's staining (Lillie 1928). Biochemical tests were performed according to the methods described by Merchant and Packer (1967).

Cultivation of Salmonella isolates and DNA extraction: The purity of Salmonella sp. was verified by cultural, staining and biochemical tests (Cheesbrough 2000). One colony from each sample was inoculated into $10 \mathrm{ml}$ of LB broth (Oxoid Ltd. Bahingstoke, Hamshire, England) and incubated at $37^{\circ} \mathrm{C}$ for $18 \mathrm{~h}$. One ml from each culture was taken into a sterile eppendorf tube for extraction of genomic DNA.

DNA was extracted from five field samples culturing in LB broth by using Wizard ${ }^{\circledR}$ Genomic DNA Purification Kit (Promegra Corporation. 2800 Woods Hollow Road. Madison, USA). The extracted DNA was quantified using a spectrophotometer's (Spectronic ${ }^{\circledR}$ Genetics ${ }^{\text {TM }}$ New York, USA) and expressed in $\mathrm{ng} / \mu \mathrm{l}$.

Oligonucleotide Primer and Amplification of DNA by PCR: One pair of oligonucleotide primer (SG1: 5 '-tcacga-ctt-aca-tcc-tac $-3^{\prime}$ and SG2: $5^{\prime}$-ctg-cta-tat-cag-cac-aac-3') was used to amplify the rfbS gene of Salmonella sp. that is genus specific. Primers were diluted with appropriate amount of TE Buffer $\left(p^{H:}: 8.0\right)$ and stored at $-20^{\circ} \mathrm{C}$ until use. The expected product size of this primer is $720 \mathrm{bp}$.

PCR amplification was performed in a final volume of $10 \mu l$ containing $2 \mu \mathrm{l}(50 \mathrm{ng} / \mu \mathrm{l})$ of DNA template, Taq buffer-A $1 \mu \mathrm{l}$, dNTPs $1 \mu \mathrm{l}$, primer-F $0.5 \mu \mathrm{l}$, primer-R $0.5 \mu \mathrm{l}$, Taq DNA polymerase $0.2 \mu \mathrm{l}$ and $4.8 \mu \mathrm{l}$ nuclease free water. Three independent reactions with the primers were made for DNA template. Amplification was carried out in Gene amplification PCR system 9600 Thermocycler (eppendorf, Germany), using condition modified from Doran et al., (1996). The pre-mix was then mixed well through spinning. Initial denaturation was at $94^{\circ} \mathrm{C}$ for $1 \mathrm{~min}, 94^{\circ} \mathrm{C}$ for $60 \mathrm{sec}$, annealing at $50^{\circ} \mathrm{C}$ for 60 seconds and extension at $72^{\circ} \mathrm{C}$ for 21 seconds, with a final extension at $72^{\circ} \mathrm{C}$ for 7 minutes for total 33 cycles and held for $4^{\circ} \mathrm{C}$. The amplified products were separated by electrophoresis on $1.5 \%$ agarose gel containing $5 \mu \mathrm{ml}^{-1}$ ethidium bromide with a $100 \mathrm{bp} \mathrm{ladder} \mathrm{(Promega,}$ Madison, WI, USA) as molecular weight marker (Oliveira et al. 2003).

\section{Results}

The prevalence of Salmonella sp. in hand wash of urban and suburban workers of live bird markets were $40 \%$ and $30 \%$ respectively. The prevalence of $E$. coli in nasal swabs of urban and suburban workers were $70 \%$ and $40 \%$ respectively (Table 1). The findings revealed that the prevalence of isolated bacteria was higher in urban than suburban live bird markets.

Table 1. Prevalence of bacteria in hand washes and nasal swabs

\begin{tabular}{lcccccc}
\hline \multirow{2}{*}{ Isolated bacteria } & \multicolumn{3}{c}{ Urban LBMs workers } & \multicolumn{3}{c}{ Periurban LBMs workers } \\
\cline { 2 - 7 } & $\begin{array}{c}\text { Sample } \\
\text { tested }\end{array}$ & $\begin{array}{c}\text { Occurrence } \\
\text { of isolates }\end{array}$ & $\begin{array}{c}\text { Prevalence among } \\
\text { tested cases (\%) }\end{array}$ & $\begin{array}{c}\text { Sample } \\
\text { tested }\end{array}$ & $\begin{array}{c}\text { Occurrence of } \\
\text { isolates }\end{array}$ & $\begin{array}{c}\text { Prevalence among } \\
\text { tested cases }(\%)\end{array}$ \\
\hline Salmonella sp. & 10 & 4 & 40.00 & 10 & 3 & 30.00 \\
Escherichia coli & 10 & 7 & 70.00 & 10 & 4 & 40.00 \\
\hline
\end{tabular}


Table 2. Biochemical activities of different isolated bacteria

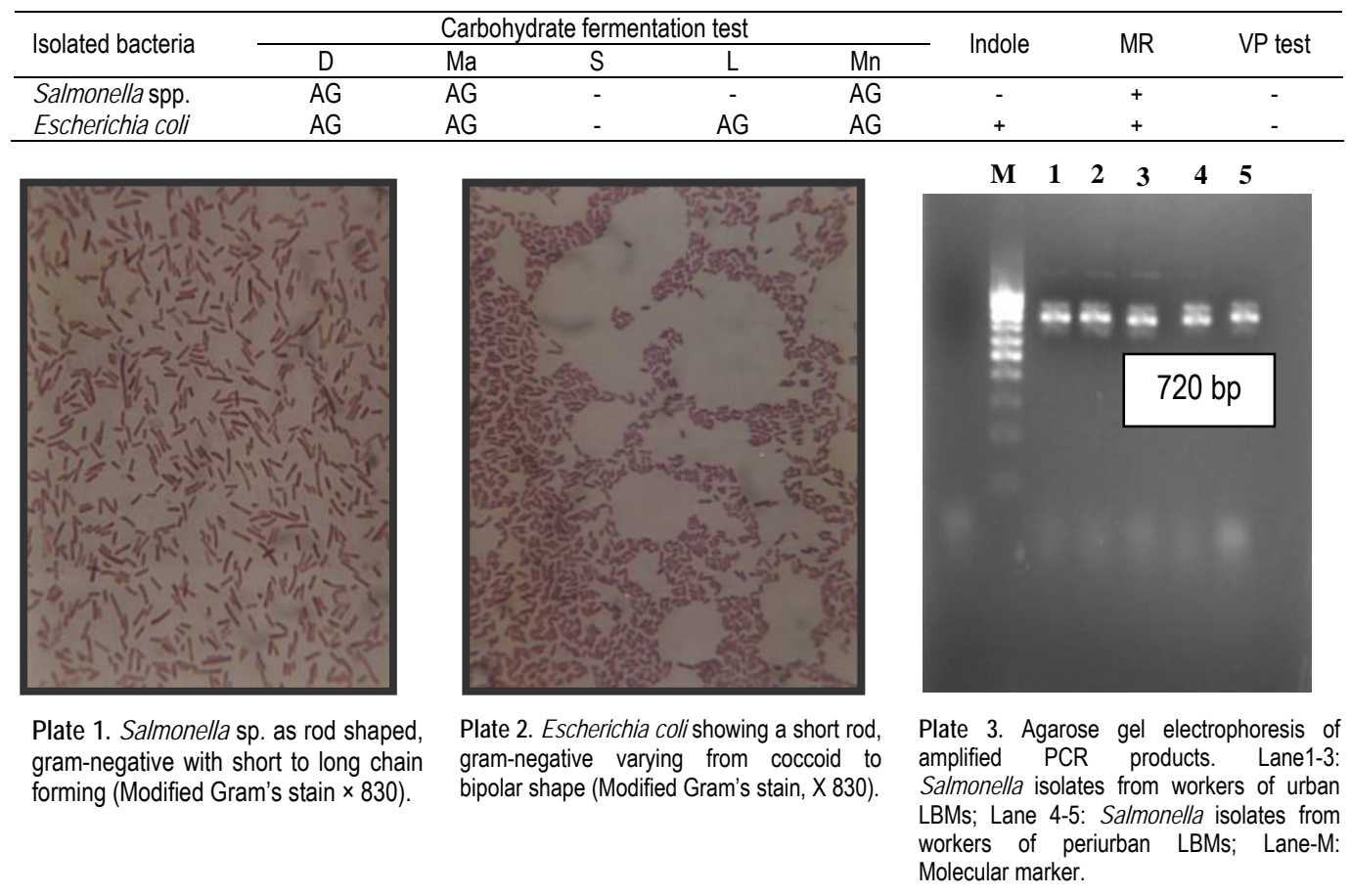

From the smear of pure cultures, Salmonella sp. revealed that the morphology of the isolated bacteria was rod shape, gram-negative and short to long chain forming (Plate 1). E. coli in smears from pure cultures, revealed that the morphology of the isolated bacteria was short rod, gram-negative varying from coccoid to bipolar shape (Plate 2). All of the Salmonella isolates fermented dextrose, maltose and mannitol but did not ferment lactose and sucrose, and all of the isolates were indole negative, methyl red positive and VP negative (Table 2). Among seven isolates, five isolates of which three isolates were from urban workers and two isolates were from suburban workers that were identified by standard culture and biochemical methods. Among five isolates, all Salmonella isolates were successfully amplified and gave an amplified product of 720 bp (Plate 3)

\section{Discussion}

The colony characters of Salmonella, showed pink white opaque colored colonies on brilliant green agar was corresponded with the findings of others (Old 1990, Yuno et al. 1995, Sharma and Katok 1996, Perez et al. 2004). Escherichia coli grew well on EMB agar and produce greenish colony with metalic sheen after 24 hours at $37^{\circ} \mathrm{C}$ which was similar with the findings of others (Jones et al. 1997, Mishra et al. 2002).

Salmonella isolates fermented dextrose, maltose and mannitol and all of the isolates were indole negative, methyl red positive and VP negative which are special biochemical characters for Salmonella sp. was previously suggested by Christensen et al. (1993) and Robinson et al. (2000). E. coli on the otherhand failed to ferment sucrose whereas dextrose, lactose, maltose and mannitol were fermented with production of acid and gas, and all of the isolates were indole positive, methyl red positive and VP negative which are special biochemical characters for this bacterium was similar to the reports of others (Jones et al. 1997, Mishra et al. 2002). Among five isolates, all Salmonella isolates were successfully amplified and gave an amplified product of 720 bp and this result was coincides with the result of Park et al. (2001). 


\section{Conclusion}

The presence of salmonella sp. and $E$. coli in hand washes and nasal swabs of workers in live bird markets indicates the biosecurity index. In near future, the attempts should be taken to identify the specific causative agents. The findings of this investigation will help the veterinarian or physician to take necessary steps to prevent zoonotic diseases.

\section{Acknowledgements}

The authors would like to express gratitude to the Department of Pathology, Bangladesh Agricultural University, Mymensingh for providing laboratory facilities with necessary research materials.

\section{References}

Carter GR. 1979. Diagnostic Procedures in Veterinary Bacteriology and Mycology. $3^{\text {rd }}$ edn. Charles C. Thomas Publisher, Springfield, 157-161 pp.

Cheesbrough M. 2000. District Laboratory Practice in Tropical Countries, Pt- 2. Cambridge University Press, 64-65 pp.

Christensen JP, Olsen JE, Bisgaard M. 1993. Characterization of Salmonella enterica serotype gallinarum biotypes gallinarum and pullorum by plasmid profiling and biochemical analysis. Avian Pathol 22, 725-738.

Doran JL, Collinson SK, Clouthier SC, Cebula TA, Koch WH, Burian J, Banser PA, Todd ECD, Kay WW. 1996. Diagnostic potential of sefA DNA probes to Salmonella enteritidis and certain other O-serogroup D1 Salmonella serovars. Mol. Cellular Probes 10, 233-246. doi:10.1006/mcpr.1996.0033

Freeman BA. 1985. Burrow's Text Book of Microbiology. 22 edn. W. B. Saunders Company, London, 372-472 pp.

Jones TC, Hunt RD, King NW. 1997. Diseases caused by bacteria. In Veterinary Pathology, Williams, Wilkins (ed), 413-504.

Joshi DD, Maharjan M, Johansen MV. 2003. Improving meat inspection and control in resource-poor communities: Nepal example. Acta Tropica 87, 119-127.

Lillie RD. 1928. The Gram Stains I: A quick method for staining Gram-positive organisms in the tissues. Arc Pathol 5, 828.

Merchant IA, Packer RA. 1967. Veterinary Bacteriology and Virology. 7thed. The lowa State University Press, Ames, 211-305 pp.

Mishra A, Sharda R, Chhabra D, Moghe MN. 2002. E. coli isolated from domestic poultry farm. Indian J Anim Sci 72(9), 727-729.

Murray CJ. 2000. Environmental aspects of Salmonella. In: Salmonella in Domestic Animals, CAB International, 265-283.

Old DC. 1990. Salmonella. In: Systematic Bacteriology, Parker MT, Duerden BI (eds),. $8^{\text {th }}$ edn, Edward Arnold, 188 pp.

Oliveira SD, Roclenbuisch CR, Ce MC, Rocha SLS, Canal CW. 2003. Evaluation of selective and non-selective enriched PCR procedures for Salmonella detection. Lett Appl Microbiol 36, 217-221.

Park MK, Choi KS, Kim MC, Chae JS. 2001. Differential diagnosis of Salmonella gallinarum and Salmonella pullorum using PCR-REFL. J Vet Sci 2, 213-219.

Perez C, Rivera S, Pirela A, Rincon H, Mavarez Y, Roman R. 2004. Isolation of Salmonella in poultry carcasses and evaluation of the effectiveness of different enrichment and selective media. Revista Cientifica Facultad Ciencias Veterinarias Universidad del Zulia 14, 177-185.

Robinson H, Mdegela MGS, Yongolo U, Minga M, Johin E. 2000. Molecular epidemiology of Salmonella gallinarum in chickens in Tanzania. Avian Pathol 29, 457-463. doi:10.1080/030794500750047216

Sharma M and Katock RC. 1996. Deadly outbreak in chicks owing to Salmonella typhimurium. Indian J Poul Sci 31, 60-62.

Sockett PN. 1991. The economic implications of human Salmonella infection. J Appl Bacteriol 71, 289-295.

Tizard I. 2004. Salmonellosis in wild birds. Seminars in Avian and Exotic Pet Medicine 13, 50-66.

Yuno MML, Terzolo HR, Fernandez HD, Malena RC, Altuna ME. 1995. Evaluation of selective culture media for isolation of Salmonella from poultry. Rev Argentina Microbiol 27, 57-69. 